Submitted 08.08.2016. Approved 18.11.2016.

Evaluated by double blind review process.

DOI: http:///dx.doi/10.12660/joscmv9n2p28-48

\title{
A SIMULATION OF CONTRACT FARMING USING AGENT BASED MODELING
}

\author{
Yuanita Handayati \\ Professor at School of Business and Management, \\ Bandung Institute of Technology - Bandung, Jawa Barat, Indonesia \\ yuanita@sbm-itb.ac.id \\ Togar M. Simatupang \\ Professor at School of Business and Management, \\ Bandung Institute of Technology - Bandung, Jawa Barat, Indonesia \\ togar@sbm-itb.ac.id \\ Tomy Perdana \\ Professor at Department of Agribusiness, \\ Faculty of Agriculture, Padjadjaran University - Sumedang, Indonesia \\ tomyperdana@gmail.com \\ Manahan Siallagan \\ Professor at School of Business and Management, \\ Bandung Institute of Technology - Bandung, Jawa Barat, Indonesia \\ manahan@sbm-itb.ac.id
}

\begin{abstract}
This study aims to simulate the effects of contract farming and farmer commitment to contract farming on supply chain performance by using agent based modeling as a methodology. Supply chain performance is represented by profits and service levels. The simulation results indicate that farmers should pay attention to customer requirements and plan their agricultural activities in order to fulfill these requirements. Contract farming helps farmers deal with demand and price uncertainties. We also find that farmer commitment is crucial to fulfilling contract requirements. This study contributes to this field from a conceptual as well as a practical point of view. From the conceptual point of view, our simulation results show that different levels of farmer commitment have an impact on farmer performance when implementing contract farming. From a practical point of view, the uncertainty faced by farmers and the market can be managed by implementing cultivation and harvesting scheduling, information sharing, and collective learning as ways of committing to contract farming.
\end{abstract}

KEYWORDS: Contract farming, agent based modeling and simulation, commitment, cultivation and harvest scheduling, supply chain performance. 


\section{INTRODUCTION}

These days consumers of agricultural products have become increasingly aware of and concerned about the availability, quality, and safety of the food they consume (Engelseth, Takeno, \& Alm, 2009; Hastuti, 2007). This change in consumer behavior represents a challenge to firms, exporters, intermediaries and retailers of traditional and modern distribution channels in terms of meeting consumer demands (Adebanjo, 2009). This challenge is related to the ability of agricultural producers to supply the quality required by their customers. In developing countries, this challenge is more complex due to the characteristics of farmers as agricultural producers. They are usually small-scale farmers who have limited knowledge and limited access to technology and market information. They farm using traditional methods, and their agricultural routines are bases on their own needs and wants, rather than consumer needs.

Agricultural supply chains in developing countries, especially in Indonesia, are typically long supply chains, which mean that they consist of more than two actors. Moreover, farmers depend on intermediaries who provide them with access to the market. The products that these farmers sell fluctuate in terms of quality, quantity and price (Sutopo, Hisjam, \& Yuniaristanto, 2012). These farmers do not have much bargaining power in negotiating with these traders, because they have limited resources. Therefore, they tend to accept any price that the intermediaries offer (Widyarini, Simatupang, \& Engelseth, 2016). There is no written contract in these partnerships, and farmers and intermediaries can pull out of their agreements at any time, so it is hard to maintain long, sustained partnerships. This leads to uncertainties in terms of demand and prices for farmers and uncertainty in terms of agricultural supply for intermediaries.

Contract farming is proposed not only as an alternative for dealing with demand and price uncertainties, but also as global optimization and a win-win solution for agricultural producers, intermediaries, firms, exporters, and customers (Pandit, Lal, \& Rana, 2015; Young \& Hobbs, 2002). Contract farming establishes a fixed price that the farmers will receive as agricultural producers. Moreover, the contract farmer also sets the quantity, quality, and the time of delivery of these agricultural products, which are supplied by farmers to intermediaries, firms, or exporters based on their customer requirements (Pan- dit et al., 2015; Young \& Hobbs, 2002). Consumers can thus find the good and safe agricultural products that they want (Pandit et al., 2015).

Several studies mention that the implementation of contract farming requires commitment from all of the involved parties (Imbruce, 2008; Minot, 2007; Pultrone \& Silva, 2012). Commitment is a willingness to give your time and energy to something that you believe in. In this study, commitment is used in the context of the farmers' willingness to give their time and energy in fulfilling what has been written in the farming contract. The terms of farming contracts are usually violated by farmers who provide agricultural products of low quality that does not meet the farming contract's requirements, or by selling their products to other parties who offer a higher price (Guo, Jolly, \& Zhu, 2007). Regarding the commitment of farmers to contract farming, Guo et al. (2007) state that the education level of farmers has a positive relationship with their participation in, and their commitment to, contract farming. However, previous studies have not sufficiently elaborated the impact of this coordination process and farmer commitment to contract farming on supply chain performance. Therefore, this study seeks to analyze the implementation of contract farming. We have adapted a case study within the Pangalengan cluster in West Java, Indonesia. A preliminary study has been carried out to describe the journey of the Pangalengan cluster to gaining access to a structured market, focusing on the problems that the farmers faced and the coordination mechanism that they have implemented. The current study extends the coordination process and studies the impact of this coordination mechanism and the commitment to contract farming on farmer supply chain performance.

This study is organized in the following manner. First we have offered some background to this research area. Second, we will present a review of the literature related to contract farming and agriculture in Indonesia. Third, we will discuss agent based modeling and our research framework as part of this study's methodology. We then present and discuss the simulation results. Finally, we will offer our conclusions.

\section{LITERATURE REVIEW}

In this section, the concept of contract farming, and the specific characteristics of agriculture and the case study are explained. 


\subsection{Contract Farming}

Definitions of contract farming have been offered by several researchers:

"a binding arrangement between a firm or contractor and an individual producer or contractee in the form of a 'forward agreement' with well-defined obligations and remuneration for tasks done, often with specifications on product properties such as volume, quality, and timing of delivery" (Catelo \& Costales, 2008).

"Agricultural production carried out according to a prior agreement in which the farmer commits to producing a given product in a given manner and the buyer commits to purchasing it" (Minot, 2007).

"A contractual arrangement between farmers and other firms, whether oral or written, specifying one or more conditions of production, and one or more conditions of marketing, for an agricultural product, which is nontransferable" (Rehber, 2007).

From these definitions, contract farming can be defined as agreements between farmers as producers and firms as buyers to stipulate the specifications of an agricultural product (volume, quality, and delivery time) at an agreed to price. Moreover, according to Rehber (2007), contract farming occurs when farmers and firms make a contractual arrangement involving production and marketing conditions for an agricultural product and the contract is non-transferable. The production conditions may include product types and characteristics, farming schedules, and the use of specific farming techniques and resources. As for the marketing conditions, they usually include a fixed price for the products and payment time. These conditions help farmers in obtaining more stable product prices and knowledge about current farming techniques, making the agricultural product market more structured. Contract farming also entails a commitment to fulfilling contract requirements by both the farmers and the firms.

People started applying the concept of contract farming around 100 years ago. It was first used by the Japanese in Taiwan during the nineteenth century (Little \& Watts, 1994). It was also used in Europe, specifically within the seed industry, before the Second World War (Rehber, 2007). Since then, contract farming has become widespread, and it accounted for up to $39 \%$ of the total value of US agricultural production in 2001 (Young \& Hobbs, 2002).
The use of contract farming in other areas of the world has also increased quite significantly, especially in Southeast Asia. In Indonesia, contract farming is promoted by the government through the Federal Land Development Agency (FELDA) (Rehber, 2007). In Malaysia, contract farming mostly involves state-promoted out grower arrangements (Morrison, Murray, \& Ngidang, 2006). In Vietnam, $90 \%$ of cotton and fresh milk, and over $40 \%$ of rice and tea also come from contract farming (UNCTAD, 2009).

Based on the detailed information mentioned in the contract, farming contracts can be categorized into three types, namely market-specification contracts, resource-providing contracts, and production-management contracts (Prowse, 2012). First, marketspecification contracts give a guarantee to farmers in terms of price, delivery time, and marketing outlets, as long as the customer's quality requirements are met. In this type of contract, farmers retain full control over the production process. Second, resourceproviding contracts state that agricultural input will be provided to the farmers in order to assure the quality of the agricultural product. This contract is usually used for crops that require specific inputs or quality standards, where farmers find it difficult to supply the agricultural inputs. Third, productionmanagement contracts discuss the role of firms, intermediaries, exporters, and/or retailers in the production process. In this type of contract, farmers do not have full control over their production process.

\subsection{Agricultural Product Characteristics}

The specific characteristics of agricultural products that differ from other products are seasonality, perishability, safety, and traceability throughout an end-to-end supply network (Taylor \& Fearne, 2006; Van der Vorst, Beulens, \& Van Beek, 2000). Furthermore, intermediary trading organizations in the food industry have been facing the challenges of coordinating retail promotions with lead time requirements and a generally low degree of supply chain flexibility and limited supply requirements (Adebanjo, 2009). Moreover, Bijman, Omta, Trienkens, Wijnands, and Wubben (2006) have suggested that an increased interorganizational collaboration in terms of the food supply may be due to: the rise of food safety as a prominent societal issue; the raw materials in food distribution that often closely resemble the finished product; and the fact that foods are to varying degrees always perishable goods. Fresh foods, 
e.g. freshly-packed seafood, are perishable products. This may then limit the timeframe for their transformation during the supply stage.

Fresh food distribution involves specific challenges, i.e. "... (i) fresh products are not standard and are subject to quality deterioration, (ii) there is a lack of clear product descriptions and coding standardization, (iii) information requirements differ with each customer, making standardization complex, and (iv) farmers utilize a relatively low degree of automation" (Van der Vorst et al., 2000).

Furthermore, food consumption is a vital aspect of human well-being. Thus, food supply chains seek to balance food safety, which is an ethically-laden societal aim, with the economic needs of supplying "quality" (Engelseth et al., 2009). "Safety" in the food supply denotes food product features measurable through the supply chain in terms of human well-being, which are dependent on technical details, while "quality" involves product attributes measured in relation to customer satisfaction. According to Becker (2000), food product quality involves product-oriented quality, process-oriented quality, and consumer-oriented quality.

\subsection{Agriculture in Indonesia: A Case Study}

In contrast to farmers in developed countries who have greater access to markets, and more knowledge, skill, and information about current farming technology, farmers in Indonesia are predominantly small scale and are characterized by not having access to the market, mostly selling their agriculture products to intermediaries, and a lack of knowledge and information about current farming technology. In practice, most small Indonesian farmers sell their agricultural products to intermediaries. Moreover, the relationships between farmers and intermediaries are not only based on transactions and commerce. They are also based on family, religious, and ethnic links. In these partnerships, there is an information gap in terms of demand and prices. Farmers do not have the bargaining power to push demand and set the selling prices that intermediaries offer (Widyarini et al., 2016).

In addition, these farmers have to deal with high uncertainty along with high risks, since they do not know the extent of market demand and prices may fluctuate based on the number of products on the market. The more agricultural products available on the market, the lower the price will be. With these conditions, it is difficult to improve the welfare of these small farmers. Moreover, the use of traditional farming methods can be observed from farmers' cultivating and harvesting decisions. Small-scale farmers usually look at their neighbors in deciding which products to plant, and do not have plans in terms of when to plant and how much to plant. Moreover, these farmers do not have plans related to when they should harvest and how much they should harvest within a given period. Usually harvesting occurs during a short period of time, and selective harvesting is not implemented.

In our current study, we use a case study administered within the Indonesian horticulture industry. In fact, this industry is dominated by small-scale farmers who are usually scattered all over the country. In addition, there is a relatively low level of competency in terms of farming and management practices. Another characteristic of this industry is the role of the intermediate actors, who are known as "tengkulak" (middlemen). They play an important role in the distribution of horticultural products in Indonesia. These characteristics have made food production and efficient coordinated food distribution in Indonesia challenging.

We have selected the Pangalengan region in West Java for this case study due to its importance in producing and distributing horticultural products, produced not only for the domestic market, but also for international markets as well (see Figure 1). The Pangalengan cluster is one of the most vital fruit and vegetable centers in West Java, Indonesia. In the past, farmers had limited information related to market demand and prices. Farmers did not have any access to a structured market, and only dealt with intermediaries or brokers to sell their products. Direct sales to intermediaries or brokers did not require good post-harvest handling for fruit and vegetable products. By developing a partnership model within a cluster, these farmers have been able to deal with several constraints. Price fluctuation is a major challenge to these fruit and vegetable farmers. In addition, these farmers have limited access to appropriate technologies, counseling services, and therefore perceive themselves individually as weak players in this regional marketplace. 
Figure 1. The Pangalengan Region as a Case Study

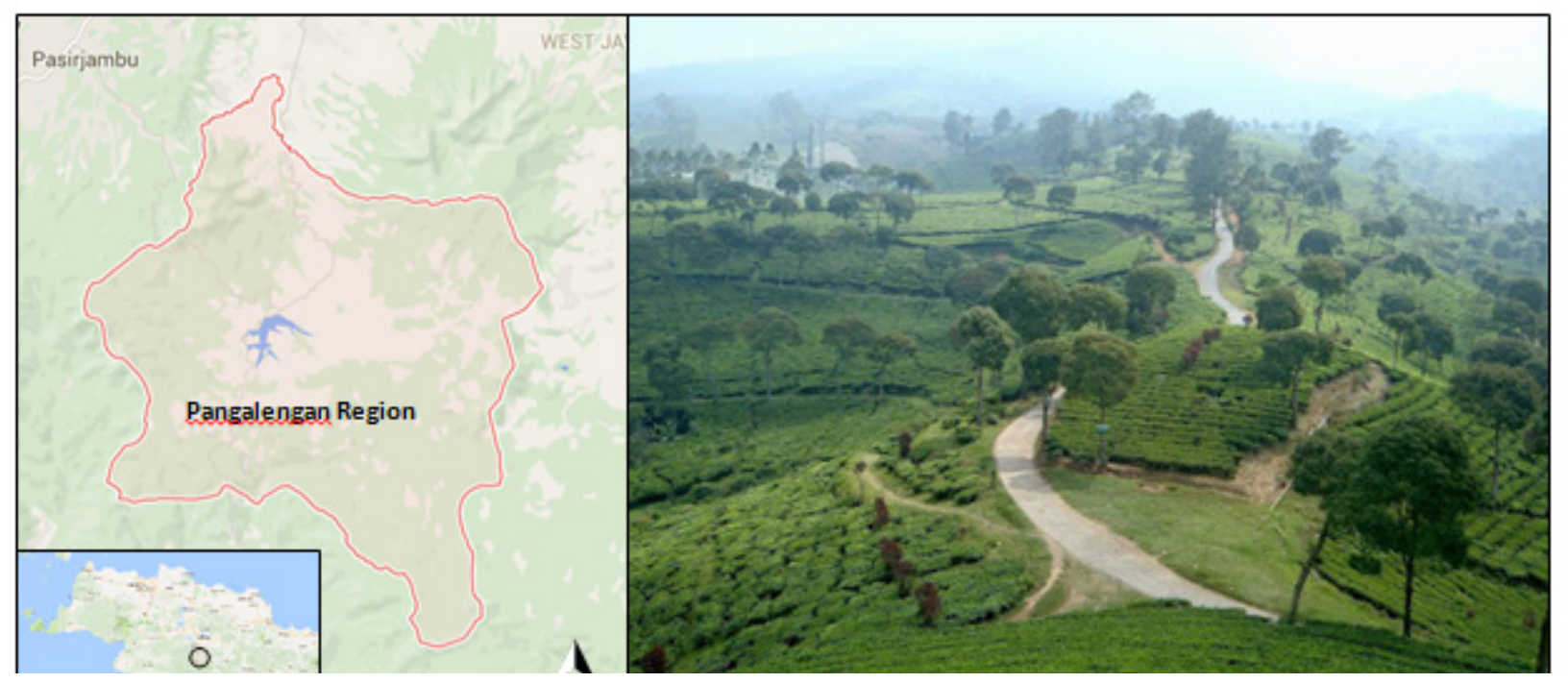

In 2009, Padjajaran University established the Value Chain Center (VCC) which has played the role of connecting farmers with the market in order to raise the competitiveness of West Javan agribusiness (Perdana \& Kusnandar, 2012). In the same year, the VCC also began a partnership with farmers in Pangalengan. The partnership went well, so in September 2013 the cluster became an organized entity created by the VCC to maintain price stability from the farmers to the market. Besides this, using the concept of a "cluster" has meant that farmers can make direct sales to a structured market and build partnerships with private companies and governmental agencies. Furthermore, the role of the VCC in creating the Pangalengan cluster has given other companies, willing to join and build partnerships with the cluster, access to a structured market.

In the beginning of this partnership between farmers and structured markets, there is a contract that sets out the structured market requirements including the quantity of agricultural products, their quality and price, and when they need to be delivered. Structured markets know the needs and wants of their consumers. Consumer information needs are shared with the farmers. These consumer needs are fulfilled by farmers by applying one or more coordination mechanisms, such as collective learning, joint decision making, and information sharing with other farmers or with the VCC and other institutions as well as with the structured market. These coordination mechanisms are used to achieve goals, namely selecting the best agricultural inputs, designing cultivation, planning harvesting, and developing and implementing standard operational procedures, etc.

Practically, providing a structured market with agricultural products that can fulfill their requirements is not easy. Farmers choose specific varieties in accordance with cultivation techniques that may produce expected yields. These farmers used to implement traditional cultivation techniques or learn on their own. If the market desires particular agricultural products, it is important to provide farmers with training in terms of the necessary cultivation techniques. The VCC can also help train these farmers. To maintain continual high productivity, cultivation and harvest scheduling needs to be well planned. Cultivation and harvest scheduling are important to making sure that the market has a sustainable supply of agricultural products from farmers. If cultivation and harvest scheduling are not implemented by these farmers, there will be periods when farmers cannot supply the market with enough of their agriculture products because there is no farmer cultivating these agricultural products at the time. There will also be periods in which the supply will be excessive because most of the farmers' agricultural production occurs at the same time. In terms of implementation, farmers still lack the commitment to follow these schedules, which have already been proposed by the cluster and the VCC. 


\section{THE AGENT BASED MODEL}

\subsection{Model Objective and Overview}

In this study, we use agent based modeling to simulate three different scenarios related to the implementation and impact of contract farming and farmer commitment to meeting the contract requirements. Each scenario simulates agent interactions that have an impact on supply chain performance. As mentioned by Tangpong, Hung, and Li (2014), the interactions among supply chain agents gives an idea of the emerging properties of a supply chain system. In this study, the impact of each scenario in terms of supply chain performance is represented by farmer profits and service levels. This study uses tomatoes as the simulated commodity. The differences between the three scenarios can be seen in Appendix 1.

This study simulates the coordination process and farmer behavior in cultivating tomatoes, harvesting them until the tomato plants die off, sending the harvested tomatoes to the farmer association (KATATA) for contract quality products and to intermediaries (the traditional market) for non-contract quality products, and the farmers receive payments from both the structured and traditional markets through KATATA. The values for the variables in this simulation have been derived from interviewing the manager of KATATA (the coordinator of the Pangalengan cluster), the head farmer, and the farmer advisor, conducting on-site observations, and searching for secondary data especially in terms of tomato prices in local markets. The interviews were conducted from January through April 2016. The interviews ranged from 30 to 120 minutes in length.

For all of the scenarios, the farmers' harvested products can be categorized into two types, namely contract quality products that meet the farming contract requirements, and non-contract quality products that do not meet the farming contract requirements. The contract quality products are sold at the price fixed in the farming contract, while the non-contract quality products are sold at a free market price. In the first scenario, there is no farming contract in the partnerships between the farmers and the free market or intermediaries. Information about demand and prices is not available before farmers start their cultivation activities. Therefore in this scenario, farmers make their decisions in terms of when to plant and how much to plant based on their experience, not on customer orders. Based on the interview with the farmers, the prices that farmers get when they sell their products on the free market fluctuate in every period. Therefore in our simulation, the agricultural product price is random and follows a normal distribution, with the minimum price being IDR 200 per $\mathrm{kg}$ and the maximum price being IDR 10,000 per $\mathrm{kg}$. However, the free market can absorb all the harvested products produced by the farmers.

In the second scenario, a farming contract is used in the partnerships between the farmers and the structured market. The farming contract sets out the demand requirements that need to be met by farmers in each period, and the price that farmers will receive when they sell their agricultural products to the structured market. The structured market has an initial demand of 3 metric tons of tomatoes. In the second scenario, the price that the farmers will receive is fixed. The structured market's price for tomatoes is IDR 7,750 per $\mathrm{kg}$. In the second scenario, farmers are still not committed to contract farming in their efforts to meet the requirements agreed to by both the farmers and the structured market. Decisions in terms of when to plant are still made by each farmer and are not made jointly. In the third scenario, the farmers are committed to contract farming and implement joint decision making, information sharing, and collective learning to meet contract requirements.

Based on the simulation flow in Appendix 2, the simulation begins with farmer decisions related to when to plant and how much to plant. In scenarios 1 and 2, the number of farmers that plant the agricultural product in every period is not the same. This happens because in scenarios 1 and 2 the farmers do not use cultivation and harvest scheduling. From our interview with the farmers, we know that 1 tomato plant with good agricultural practices can yield a maximum of $2 \mathrm{~kg}$ of tomatoes per week during the harvesting period. Each harvesting period lasts six consecutive weeks. The quantity of products harvested each week during the harvesting period is not the same. In weeks 1 and 6, farmers can only harvest $40 \%$ of the expected yield $(0.168$ metric tons per farmer). In weeks 2 and 5, farmers can only harvest $50 \%$ of the expected yield ( 0.21 metric tons per farmer). During weeks 3 and 4, with the farmers are able to harvest $90 \%$ of the expected yield $(0.378$ metric tons per farmer). In scenario 3, there are 10 farmers assigned to plant this agricultural product in each period in order to meet demand requirements and achieve a stable supply. Each farmer should therefore cultivate 210 plants. While the tomatoes are still 
harvestable, the farmers repeat the process of sending tomatoes to KATATA and receiving money from KATATA. KATATA also repeats the process of sending tomatoes to structured and traditional markets, and sends the money from both markets to the farmers. The farmer service levels and profits are calculated for each period.

When farmers use cultivation and harvest scheduling, the second group of farmers starts their cultivating activities 28 days after the previous group has begun their cultivation activities. For example, if group 1 has a 0 -day delay, group 2 will have a 28day delay, group 3 will have a 56-day delay, and so on. After planting their agricultural products, the farmers wait for 90 days until their tomatoes are ripe and ready to be harvested. If the scheduling option is not used, each farmer can individually choose when to plant their agricultural products. To validate the model, the simulation results have been confirmed with the manager of KATATA.

This study uses Relogo, a simple version of Repast, a Java Groovy-based programming language for agent based modeling and simulations (http://www. repast.sourceforge.net). It is an open-source simulation framework for agent based modeling, based on the Java programming language. Basically, the Java version of Repast is supposed to be used by users familiar with Java who need to create advanced complex simulations. For new users with limited knowledge of Java, it is suggested that they use Relogo, a simpler version of Repast, which is based on Groovy, a programming framework for Java. While in our simulation the customization of some agent actions is needed, this tool makes it easier to create advanced complex simulations.

We use an agent based simulation to prove the hypothesis of this study. Our hypothesis is that supply chains featuring contract farming with farmer commitment outperform those featuring contract farming without farmer commitment and are better than the free market mechanism based on average profits and service levels. With a commitment to contract farming, farmers can coordinate their agricultural activities to fulfill contract requirements.

\subsection{Agents}

Based on our case study, there are four main agents in the Pangalengan cluster, namely the free market; the structured market; KATATA as the coordinator of the Pangalengan cluster; and the Pangalengan farmers. Pangalengan farmers are divided into three categories based on their agricultural practices. Farmers within the first group have poor agricultural practices. Fifteen farmers from the Pangalengan cluster can be included in this category. Farmers within the second group have fair agricultural practices. Fifteen farmers can be included in this category. Farmers within the third group have good agricultural practices. Twenty farmers can be included in this category.

These different types of farmers produce different quantities of contract quality products. Only 10\% of the tomatoes produced by farmers with poor agricultural practices are of sufficient quality to meet contract standards, and it will cost them IDR 3,000 per plant, given that one plant is equal to 2 kilograms of tomatoes. Farmers with fair agricultural practices will have $30 \%$ contract quality tomatoes and it will cost them IDR 4,000 per plant, while farmers with good agricultural practices will produce $80 \%$ contract quality tomatoes, but it will cost them IDR 6,000 per plant. It is assumed that all of the contract quality tomatoes will be sold to the structured market, and all of the non-contract quality tomatoes that cannot fulfill the contract requirements will be sold on the free market.

\subsection{Agent Behavior}

In the third scenario, farmers can change their behavior based on their collective behavior. In this simulation, farmers can change their agricultural practices based on their observation of their neighbors' behavior. As mentioned by Bianchi and Squazzoni (2015), our decision making is usually influenced by observing the behavior of others. Farmers will improve their agricultural practices if they observe their neighbors implementing better agricultural practices and getting better profits. There is also a chance that farmers will degrade their agricultural practices if their neighbors get better profits though implementing worse agricultural practices. They might also decide to quit contract farming if the neighbors implement worse agricultural practices and have greater profits with the profit coming mostly from the traditional market.

Another behavior simulated in this study is related to social punishment. Social punishment is another form of indirect reciprocity (Bianchi \& Squazzoni, 2015). In this study, social punishment is represented by the decision of farmers to exclude a farmer 
who cannot fulfill contract requirements because the farmer will not follow Standard Operating Procedures (SOP). This decision would be made because other farmers believe that the behavior of this farmer could hurt their partnership with the structured market.

\section{SIMULATION RESULTS}

The simulation results compare the impact of contract farming and farmer commitment to fulfilling contract requirements on supply chain performance, namely profits and service levels. Table 1 illustrates the comparison of profits and service levels achieved by farmers in each scenario along with the standard deviation. The average profit and service level are obtained by running the simulation 700 times, and each running consists of 500 periods. The number of repetitions was calculated based on Kelton, Sadowski, and Sadowski (2002). Moreover, to test the differences in terms of profit in Scenarios 1, 2, and 3, we used a one-way analysis of variance (ANOVA). In addition, we used the Tukey-Kramer procedure to identify which Scenario group is different. In order to test the differences among service levels in Scenarios 2 and 3, we used F-Tests for two-sample variances and t-Tests for two-sample variances assuming equal variances. The results of these tests can be seen in Tables 2 and 3 .

Table 1 shows that without contract farming (Scenario 1) farmers earn the lowest profit compared with implementing contract farming. Moreover, if contract farming is used by farmers but farmers do not commit to fulfilling contract requirements (Scenario 2), the farmers earned profit is lower than if the farmers commit to fulfilling contract requirements (Scenario 3). During each week of the harvesting period, farmers in Scenario 2 earned profits of IDR $11,776,746.97$ on average. In Scenario 3, the farmers earned profits of IDR 15,369,211.58 per week.

Table 1. Comparison of Profits in Scenarios 1, 2, and 3

\begin{tabular}{llll}
\hline & Scenario 1 & Scenario 2 & Scenario 3 \\
\hline Profits & IDR 5,368,258.30 & IDR 11,776,746.97 & IDR 15,369,211.58 \\
Standard deviation & IDR 5,074,632.90 & IDR 6,029,624.23 & IDR 2,855,707.02 \\
\hline
\end{tabular}

Table 2. Result of Anova: Single Factor Test

SUMMARY

\begin{tabular}{|c|c|c|c|c|c|c|}
\hline Groups & Count & \multicolumn{2}{|c|}{ Sum } & Average & \multicolumn{2}{|c|}{ Variance } \\
\hline Scenario 1 & 700 & \multicolumn{2}{|c|}{$3,757,791,227.50$} & $5,68,274.61$ & \multicolumn{2}{|c|}{$40,929,666,151.05$} \\
\hline Scenario 2 & 700 & \multicolumn{2}{|c|}{$8,243,742,278.32$} & $11,776,774.68$ & \multicolumn{2}{|c|}{$51,319,696,247.12$} \\
\hline Scenario 3 & 700 & \multicolumn{2}{|c|}{$10,758,448,105.33$} & $15,369,211.58$ & \multicolumn{2}{|c|}{$43,732,459,023.36$} \\
\hline \multicolumn{7}{|c|}{ ANOVA } \\
\hline Source of Variation & SS & df & MS & $\mathbf{F}$ & p-value & F-crit \\
\hline Between Groups & $3.59318 \mathrm{E}+16$ & 2 & $1.79659 \mathrm{E}+16$ & $396,359.05$ & 0 & 4.615298 \\
\hline Within Groups & $9.50513 E+13$ & 2097 & \multicolumn{2}{|c|}{$45,327,273,807.18$} & & \\
\hline Total & $3.60268 \mathrm{E}+16$ & 2099 & & & & \\
\hline
\end{tabular}

The hypotheses used in the ANOVA are:

H0: means for Scenario 1 = Scenario 2 = Scenario 3

H1: means for the scenarios are not all the same
The result of the ANOVA test with a significance of $1 \%$ in Table 2 shows that the means for Scenarios 1, 2, and 3 are not all the same (F-test $=396,359$, p-value $=0$ ). 
Table 3. Results of the Tukey-Kramer Procedure

\begin{tabular}{lll}
\hline Scenario Comparison & Mean Differences & Critical Range \\
\hline Scenario 1 - Scenario 2 & $6,408,500.07$ & 3.31 \\
Scenario 1 - Scenario 3 & $10,000,936.97$ & \\
Scenario 2 - Scenario 3 & $3,592,436.90$ & \\
\hline
\end{tabular}

The Tukey-Kramer procedure with a critical range of 3.31 shows that all of the Scenarios are different (Table 3). It can be concluded that Scenario 3 is better than Scenario 2 in terms of profits, and that Scenario 2 is better than Scenario 1.

Table 4. Comparison of Service Levels for Scenarios 1, 2, and 3

\begin{tabular}{llll}
\hline & Scenario 1 & Scenario 2 & Scenario 3 \\
\hline Service Level & - & $42.16 \%$ & $93.86 \%$ \\
Standard Deviation & - & $15.93 \%$ & $14.25 \%$ \\
\hline
\end{tabular}

The simulation also shows the different service levels for each Scenario, which are displayed in Table 4 . There is no service level performance in Scenario 1, because there is no information related to customer demand. The farmer service level performance in Scenario 2 is 2 times lower than in Scenario 3. The standard deviation of service level in Scenario 2 is also lower than Scenario 3. This means that using Scenario 2, there is only $42 \%$ of structured market demand that is being met by farmers. In Scenario 3 on the other hand, the service level shows that farmers managed to meet structured market demand. In order to check the service levels of Scenarios 2 and 3, we used a t-test pooled variance to test the difference.

Table 5. F-Test for Two-Sample Variances

\begin{tabular}{lll}
\hline & Scenario 2 & Scenario 3 \\
\hline Mean & 42.15919963 & 93.8578608 \\
Variance & 0.093151249 & 2.761344456 \\
Observations & 700 & 700 \\
Df & 699 & 699 \\
F & 0.03373402 & \\
P(F $<f)$ one-tail & 0 & \\
F-critical one-tail & 0.882926931 & \\
\hline
\end{tabular}

Table 6. t-Test: Two-Sample Variances Assuming Equal Variances

\begin{tabular}{lll}
\hline & Scenario 2 & Scenario 3 \\
\hline Mean & 42.15919963 & 93.8578608 \\
Variance & 0.093151249 & 2.761344456 \\
Observations & 700 & 700 \\
Pooled Variance & 1.427247852 & \\
Hypothesized Mean Difference & 0 & \\
Df & 1398 & \\
T Stat & -809.5871746 & \\
$\mathrm{P}(\mathrm{T}<=\mathrm{t})$ one-tail & 0 & \\
$\mathrm{~T} C$ Critical one-tail & 1.645944318 & \\
$\mathrm{P}(\mathrm{T}<=\mathrm{t})$ two-tail & 0 & \\
$\mathrm{~T} C$ Critical two-tail & 1.961662333 & \\
\hline
\end{tabular}


Tables 5 and 6 show that Scenario 3 is significantly different from Scenario $2(t$ test $=-809$, $p$ value $=0)$. It can be concluded that the service level in Scenario 3 is better than in Scenario 2.

Figure 2. Service Level Performance in Scenario 3 Illustrates Farmer Behavior

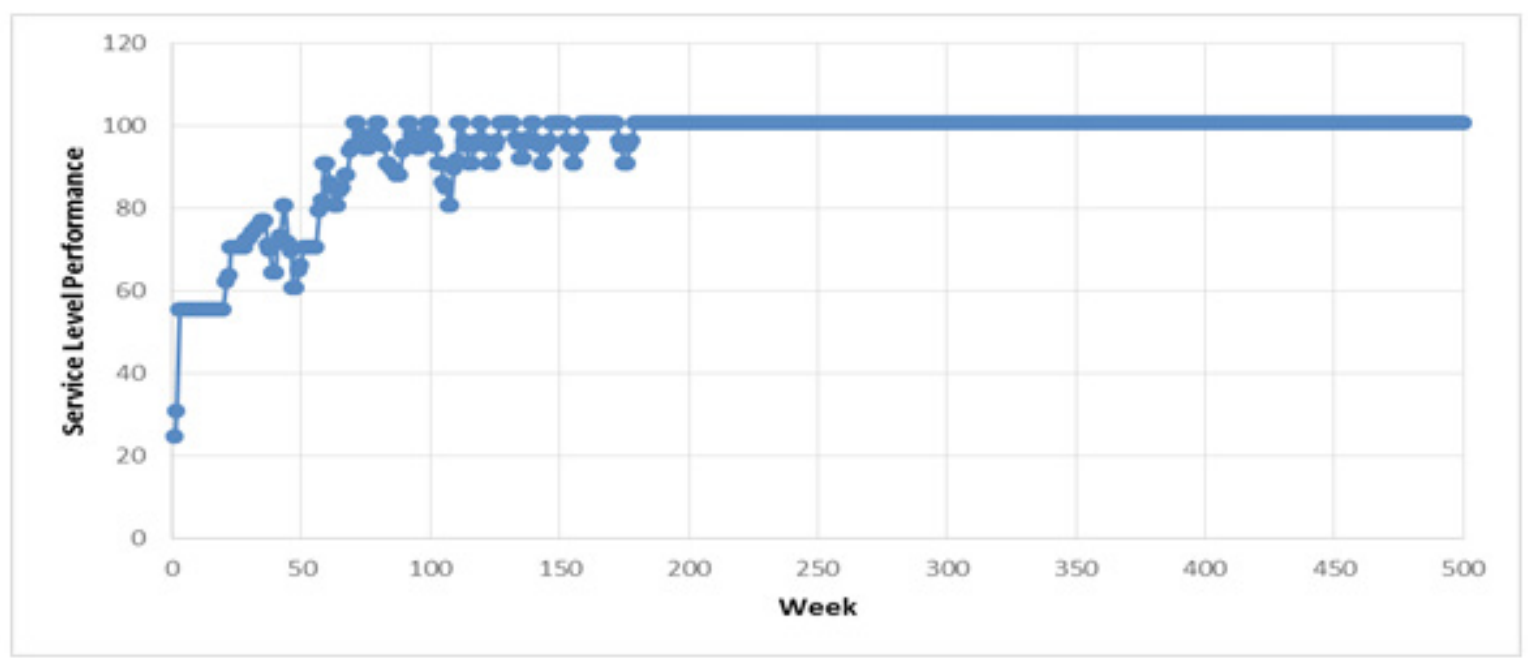

The simulation result in Figure 2 illustrates that in Scenario 3, the farmer service level can be improved over time. The improvements in service level occurred because farmers interact with other farmers and the market. In this interaction, information sharing, collective learning, and joint decision making are implemented. This implementation is related to farmer behavior in terms of SOP to increase their service levels. Social punishment is also illustrated in the simulation by assessing farmer service levels in meeting contract requirements. If over several periods, farmers cannot increase their service levels and cannot improve their SOP, the farmer cluster will ask them to withdraw from the partnership.

\section{DISCUSSION}

In this section, we explain the simulation results based on practice, observation, and our interviews. Furthermore, farmer commitment to implementing contract farming is also discussed.

5.1 Simulation Discussion for Farming without Contracts (Scenario 1)

Figure 3. Farmer Product Supply in Scenario 1

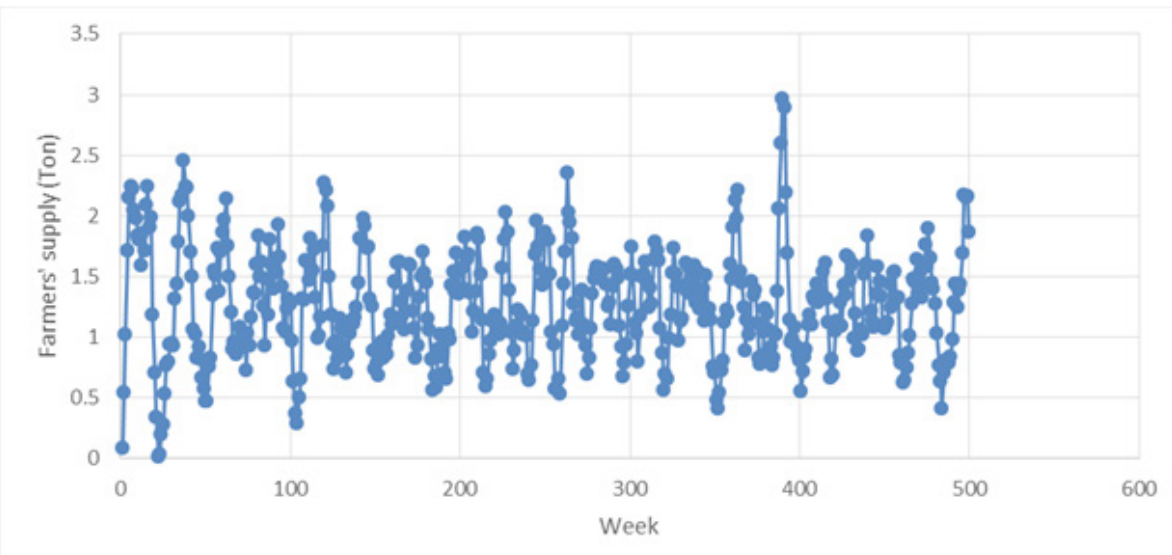


The farmer partnership in farming without contracts is an illustration of farmer partnerships with intermediaries as in the traditional market. In these partnerships, the quantity of demand and prices are not known in advance. In this kind of situation, farmers face the risk that not all of their agricultural products will be purchased by intermediaries, or that their agricultural products will be sold at low prices, which will mean their losing a lot of money.

As can be seen in Figure 3, the agricultural supply in Scenario 1 fluctuates. This fluctuation occurs because there is no coordination among the farmers. Moreover, farmers still do not realize that there is a need for coordination, because there is no information related to the customer requirements that they need to fulfill. These farmers also do not use collaborative planning in terms of cultivation and harvest scheduling. Therefore, there will be periods when farmers plant the same commodity and harvest at the same time, which will result in an excessive supply of their agricultural products. There will also be periods when their agricultural products will be very scarce, because there will be few farmers planting these commodities.

The simulation results for this situation show that without contract farming to inform them of customer demand, farmers cannot plan their cultivation decisions. Farmer decisions related to what, when, and how much to plant are only based on their past experience or the experiences of other farmers. Without cultivation planning, farmers cannot provide a sustainable supply of product for their customers because farmers do not have sustained, continuous demand from their customers. Moreover, in this situation, farmers only implement their traditional methods of farming without considering ways to apply new technology or knowledge to improve their productivity. This situation occurs because farmers have no incentive to change their current farming activities. Moreover, there is no partnership mechanism to encourage farmers to adjust or improve their farming activities or cultivation and harvest decisions.
These simulation results were confirmed by the KATATA manager and the farmer advisor in a validation process. The KATATA manager and farmer advisor agreed that when contract farming is not implemented, the situation that is illustrated in the simulation result occurs. Farmer cultivation decisions are based on their neighbors' decisions, and harvesting takes place without implementing selective harvesting. Sometimes early harvesting occurs because the farmers need money for their daily needs. In practice, sometimes an extreme situation occurs, when farmers do not harvest their agricultural products because the market price is very low. Thus, the costs of harvesting would make them suffer even greater losses.

\subsection{Simulation Discussion for Contract Farming without Commitment (Scenario 2)}

Contract farming illustrates the farmer partnership with the structured market. In contract farming, there is a demand quantity for the agricultural product and its price is clearly stated (Arshinder \& Deshmukh, 2008). The demand quantity is fixed relatively for every period so that farmers can carry out cultivation planning to fulfill the demand for each period. The key to contract farming is sustained and continuous demand and zero fluctuation in terms of demand and price. In the beginning of the contract farming implementation process, it is difficult for farmers to shift from their traditional methods of farming to more well-planned farming. The most basic way to achieve a sustained and continuous supply of agricultural products is to implementing cultivation and harvest scheduling. The implementation of cultivation and harvest scheduling involves joint decision making, information sharing, and collective learning between farmers and the market. This is in accordance with the concept of Collaborative Planning, Forecasting, and Replenishment which aims to reduce supply chain costs and promote greater integration, visibility and cooperation among supply chain members (Holmström, Främling, Kaipia, \& Saranenet, 2002). 
Figure 4. Farmer Product Supply in Scenario 2

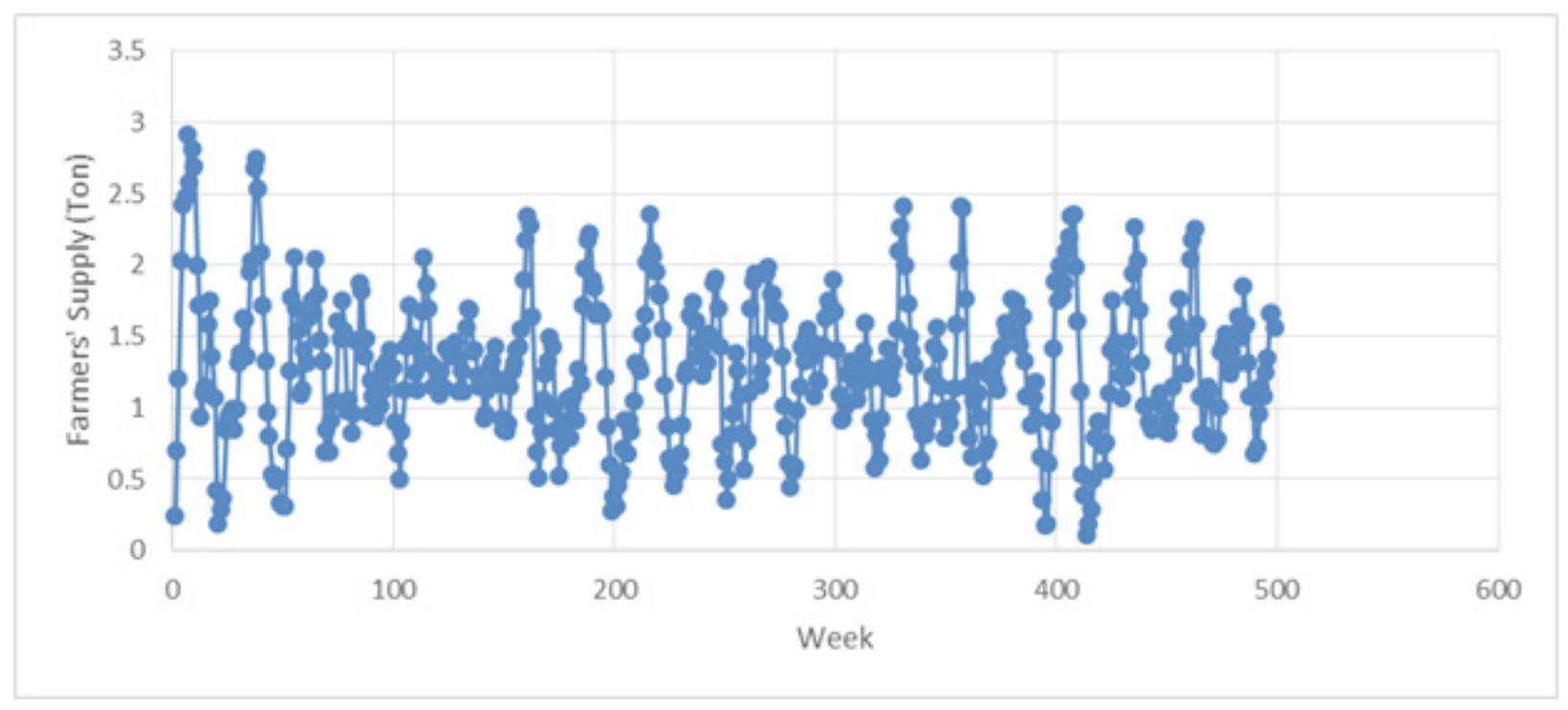

In the beginning of the contract farming implementation process, farmers still do not know how to carry out cultivation and harvest scheduling. The fluctuation in the supply of contract quality products occurs because farmers do not implement cultivation and harvest scheduling, as can be seen in Figure 4. Moreover, with contract farming, farmers' losses can be avoided because contract farming offers a stable price. Thus, farmers can make more accurate calculations of their revenue. This differs from market prices which can be very low and can result in farmers losing a lot of money.

Like the previous simulation results, the simulation results of the second scenario have been validated by confirming them with the KATATA manager and the farmer advisor. They confirmed that the simulation results are in accordance with the KATATA situation, where contract farming for a structured market has just been implemented. Having a partnership with the structured market is a new experience for KATATA, especially in terms of the structured market's complex requirements. Farming contracts spell out detailed demand requirements. Agricultural product characteristics, namely product weight, color, and shape are also spelled out in the farming contract. The quantities of agricultural products that are to be supplied every period are also stated. The price that farmers get from implementing contract farming is stable and higher than the average market price. Farmers realize that with contract farming their profits will increase. However, by comparing the complex requirements of contract farming with the requirements of the traditional market, farmers realize that they need to improve their farming activities. With the assistance of the farmer advisor, these farmers are slowly changing their cultivation decisions.

\subsection{Simulation Discussion for Contract Farming with Commitment (Scenario 3)}

In contrast to the second scenario, the third scenario shows that farmers have already completed the adaptation process and have adjusted their farming activities by developing cultivation and harvest scheduling to meet contract requirements. Farmers work together to arrange their cultivation and harvest scheduling. Farmers get together to decide when each one should plant, what to plant, and how much to plant, so that they can offer a continuous and sustained supply of agricultural products.

KATATA confirmed that the simulation results were in accordance with what has happened in KATATA when cultivation and harvesting scheduling have been implemented. The stable demand of contract farming allows farmers to develop cultivation planning. Farmers can also plan in terms of how much to plant, when to plant, when to harvest, and how much to harvest.

Using cultivation and harvest scheduling, the farmers that join KATATA should coordinate their cultivation decisions. There is a commitment from farmers to meet contract requirements, because both farmers 
and the structured market benefit from this partnership mechanism. Farmers benefit from higher profits compared with their partnerships with intermediaries. The structured market benefits from higher margins because they obtain their product supply directly from farmers, not from intermediaries. Moreover, the structured market can maintain higher quality because the distribution chain is shorter.

Figure 5. The Level of Commitment and Supply Chain Performance

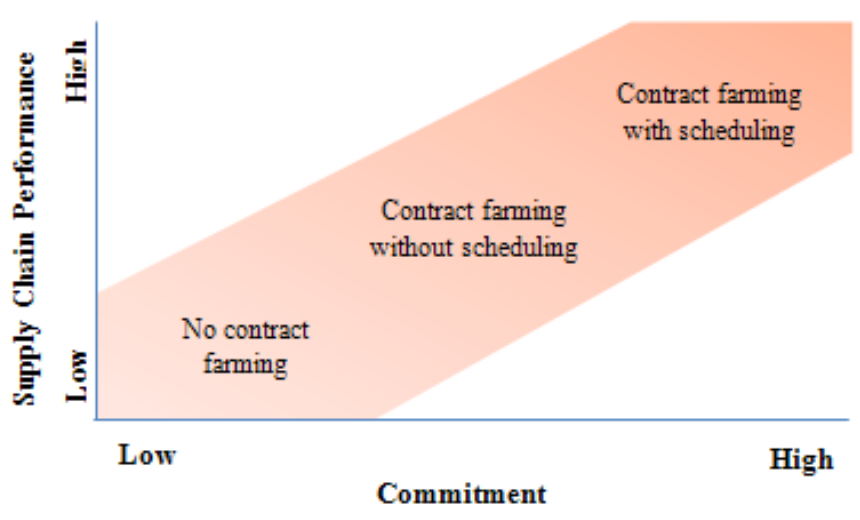

The simulation results for each scenario in the implementation of contract farming illustrate the different levels of farmer commitment, which in turn illustrates farmer commitment and its implications in terms of supply chain performance. Without contract farming, farmers do not have information related to the quantity of agricultural products that they will be able to supply during each period, so farmers do not have a commitment to meeting market demands. Furthermore, communication between farmers and their consumers is very limited. There is no bonding or incentive to encourage farmers to evaluate their farming activities to improve harvesting quantity and quality. The demand requirements in this partnership are very loose. Moreover, with contract farming, the commitment between farmers and the structured market is greater than with the traditional market in which contract farming is not implemented. Contract farming encourages farmers to have a supply target that they need to meet to achieve higher revenue. In the second scenario, farmer commitment has begun, but it is still in its early stages, because farmers are still adapting to the new partnership mechanism and the requirements can be negotiated. This situation has also been confirmed by Stringer and Sang (2009) and Burer, Jones, and Lowe (2008). Furthermore, in this second scenario, farmer commitment to contract farming requirements is still questionable. The simulation results from the third scenario show that the commitment between farmers and the structured market is well developed. Moreover, in the third scenario, the farmer commitment to meeting contract requirements is greater than in the second scenario. With this increased commitment, supply chain performance also increases. This situation has been illustrated by Kuwornu, Kuiper, and Pennings (2009), and Zylbersztajn and Miele (2005).

This study has practical implications. Supply chain performance can be improved by establishing better communication among farmers. This communication aims to motivate farmers to make a serious commitment to meeting contract requirements, and to monitor farmers in terms of the implementation of cultivation and harvest scheduling and SOP for Good Agricultural Practices. Thus, farmers who do not follow SOP, and farmers that only halfheartedly follow SOP, are encouraged to fully adopt SOP. This simulation also proves that farmers who follow SOP will have higher productivity and better supply chain performance compared to farmers who do not follow SOP or follow them halfheartedly. In general, contract farming can only have a positive impact on supply chain performance, especially in terms of farmer profits and service levels, if farmers have a commitment to meeting contract requirements by implementing cultivation and harvest scheduling and good agricultural practices.

This study has several limitations that can be improved upon by further research. This study only uses one case study to illustrate the implementation of contract farming and its effect on supply chain performance. The only commodity that was simulated in this study is the tomato, even though in reality, farming contracts can be required for more than one commodity, and one farmer can cultivate more than one commodity. The agent based simulation in this study excludes external factors such as the environment and climate which can affect agricultural production. The farming contracts illustrated in this study are fixed and given. This study does not simulate the interactions between actors in the agricultural supply chain that go into reaching agreements on the terms of these contracts.

\section{CONCLUSIONS}

The simulation results of the three scenarios illustrate that a stable supply of agricultural products 
can be achieved when contact farming is implemented and affects farmer cultivation decisions. Contract farming makes farmers eager to improve their farming activities by developing cultivation and harvest scheduling. A comparison of farmer profits in these three scenarios shows that farmer profits are lowest when there are farmer partnerships with intermediaries to meet traditional market requirements. The highest profits are achieved by implementing contract farming. Instead of a market price that is always fluctuating, prices in contract farming are stable and higher than average market prices. Moreover, cultivation and harvest scheduling make farmers create a stable supply of products and stable profits.

Williamson (1981) has stated that contract farming is used to manage uncertainty. Williamson also added that the implementation of contract farming needs to consider agent characteristics in terms of bounded rationality and opportunistic behavior. Bounded rationality is related to the agent limitations in formulating and solving complex problems and in processing information. Opportunistic behavior characterizes agents trying to maximize their own profits regardless of how this affects other agents. In this study, agent characteristics are reflected in farmer commitment to meeting contract requirements. The contribution of this study is related to the coordination process of fulfilling farming contracts and the impact of contract farming and farmer commitment on supply chain performance.

The commitment between farmers and their customers is greater when contract farming is implemented. Farmers should commit to meeting contract requirements. Greater farmer commitment can be seen by the implementation of cultivation and harvest scheduling. Contract farming also encourages farmers to improve their farming activities because farmers have a commitment to improve their productivity and quality, which is never even discussed when farmers supply intermediaries through traditional markets.

This study makes practical as well as conceptual contributions to the field. From the conceptual point of view, it differs from previous studies that have examined contract arrangements by assessing the interactions between actors (Chambers \& King, 2002; Kuwornu et al., 2009). This study has been modeled and proves that implementing contract farming affects the coordination of farmer cultivation decisions, and shows that different levels of farmer commitment affect farmer performance when contract farming is implemented. This study also shows that by using agent based modeling, the actor or agent decision making process based on their preferences can be illustrated. This study also has practical implications. Contract farming is beneficial for both farmers and the market because it efficiently manages uncertainty in terms of demand and prices for farmers and uncertainty in terms of sustainable product supply for the market. Moreover, this simulation shows that contract farming will provide farmers with larger profits. However, contract farming without farmer commitment will ruin the partnership between farmers and the market, because the farmers will not be able to fulfill the contract requirements. This simulation also illustrates that farmer commitment to contract farming will increase profits and service levels.

The practical implication of this is that the simulation's coordination process shows that farmer commitment to contract farming can be achieved by collective learning, information sharing, and joint decision making. Collective learning is related to the implementation of SOP which can be used by all farmers. Information sharing is related to the behavior of comparing profits and service levels as a result of implementing SOP. Joint decision making is related to cultivation and harvest scheduling that is agreed to and implemented by all farmers, by informing them that in order to fulfill contract requirements and achieve good service levels and profits, farmers need to have closer interactions with other farmers and their customers. Farmers should be supervised or need an advisor to provide greater knowledge and improved technology so that farmers can improve their farming activities and cultivation decisions to enter a more valuable market.

To deal with the limitations of this study, future research should focus on the coordination process or coordination mechanism at each stage of these agricultural activities. In the initial stage of agricultural activities, farming contracts are agreed to. The interactions between actors in the agricultural supply chain should be explained and included in this simulation to explain the process of agreeing to the terms of farming contracts. The coordination mechanism is not the sole mechanism for contract farming, but other mechanisms are usually used in the coordination process. The coordination mechanism should be included also in the simulation to capture the interactions between actors in the agricultural supply chain. The interaction and learning process 
of each agent in the coordination process at each stage should also be better simulated. Furthermore, external factors such as climate and environmental conditions should be included in the simulation to describe their role in affecting agricultural productivity and their influence on the coordination process. In further research, the simulation should include more than one farmer planted commodity to indicate farmer capabilities and limitations in terms of meeting contract requirements.

\section{REFERENCES}

Adebanjo, D. (2009). Understanding demand management challenges in intermediary food trading: A case study. Supply Chain Management: An International Journal, 14(3), 224-233. doi:10.1108/13598540910954566

Arshinder, K.A., \& Deshmukh, S. G. (2008). Supply chain coordination: Perspective, empirical studies and research direction. International Journal Production Economics, 115(2), 316-335. doi:10.1016/j.ijpe.2008.05.011

Becker, T. (2000). Consumer perception of fresh meat quality: A framework for analysis. British Food Journal, 102(3), 158-176. doi:10.1108/00070700010371707

Bianchi, F., \& Squazzoni, F. (2015). Agent-based model in sociology. WIRES Computational Statistics, 7(4), 284-306. doi:10.1002/ wics. 1356

Bijman, J., Omta, S.W.F., Trienkens, J.H., Wijnands, J.H.M., \& Wubben, E.F.M. (2006). International agri-food chains and networks. Management and Organization. Wagengingen, NL: Wageningen Academic Publishers. doi:10.3920/978-90-8686-573-4

Burer, S., Jones, P.C., \& Lowe, T.J. (2008). Coordinating the supply chain in the agricultural seed industry. European Journal of Operational Research, 185(1), 354-377. doi:10.1016/j. ejor.2006.12.015

CCatelo, M.O., \& Costales, A. (2008). Contract farming and other market institutions as mechanism for integrating smallholder livestock producers in the growth and development of the livestock sector in developing countries. Pro-Poor Livestock Policy Initiative, Working Paper, 45. Retrieved from http:// www.fao.org/3/a-bp187e.pdf

Chambers, W., \& King, R.P. (2002). Changing agricultural markets: Industrialization and vertical integration in the dry edible bean industry. Review of Agricultural Economic, 24(2), 495511. doi:10.2307/1349774

Engelseth, P., Takeno, T., \& Alm, K. (2009). Food safety, quality, and ethics in supply chains - a case study focusing on informing in international fish distribution. In A. Lindgreen, M. Hingley, \& J. Vanhamme, (Eds.), The Crisis of Food Brands: Sustaining Safe, Innovative and Competitive Food Supply. Aldershot UK: Gower.

Guo, H., Jolly, R. W., \& Zhu, J. (2007). Contract farming in China: Perspectives of farm households and agribusiness firms. Comparative Economy Studies, 49(2), 285-312.
Hastuti, E.Y. (2007). The influence of agribusiness system applied to vegetables farmer's income improvement in Boyolali regency. Semarang, Indonesia: Diponegoro University.

Holmström, J., Främling, K., Kaipia, R., \& Saranen, J. (2002). Collaborative planning forecasting and replenishment: New solutions needed for mass collaboration. Supply Chain Management: An International Journal, 7(3), 136-145. doi:10.1108/13598540210436595

Imbruce, V. (2008). The production relations of contract farming in Honduras. Geo Journal, 73(1), 67-82. doi:10.1007/s10708008-9179-z

Kelton, W.D., Sadowski, R.P., \& Sadowski, D.A. (2002). Simulation with arena. McGraw Hill.

Kuwornu, J.K.M., Kuiper, W.E., \& Pennings, J.M.E. (2009). Agency problem and hedging in agri-food chains: Model and application. Journal of Marketing Channels, 16(3), 265-289. doi:10.1080/10466690902934557

Little, P.D., \& Watts, M.J. (1994). Living under contract: Contract farming and agrarian transformation in sub-Saharan Africa. Madison: University of Wisconsin Press.

Minot, N. (2007). Contract farming in developing countries: Patterns, impact, and policy implications. Case Study 6-3 of the Program, Food Policy for Developing Countries: The Role of Government in the Global Food System, Cornel University.

Morrison, P.S., Murray, W.E, \& Ngidang, D. (2006). Promoting indigenous entrepreneurship through small scale contract farming: The poultry sector in Sarawak, Malaysia. Retrieved from FAO website: http://www.fao.org/ag/ags/contract-farming/agslibrary/detail-fr/fr/item/3797/icode/7/?no_cache=1.

Pandit, A., Lal, B., \& Rana, R.K. (2015). An assessment of potato contract farming in West Bengal State, India. Potato Research, 58(1), 1-14. doi:10.1007/s11540-014-9259-z

Perdana, T., \& Kusnandar. (2012). The triple helix model for fruits and vegetables supply chain management development involving small farmers in order to fulfill the global market demand: A case study in "value chain center (vcc) universitas padjadjaran". Procedia Social and Behavioral, 52, 80-89. doi:10.1016/j.sbspro.2012.09.444

Prowse, M. (2012). Contract farming in developing countries - a review. A Savoir, Institute of Development Policy and Management, University of Antwerp.

Pultrone, C., \& Silva, C.A. (2012). Guiding principles for responsible contract farming operations. Rome, Italy: Rural Infrastructure and Agro-industries Division, FAO. Retrieved from http:// www.fao.org/docrep/016/i2858e/i2858e.pdf

Rehber, E. (2007). Contract farming: Theory and practice. Hyderabad, India: ICFAI University Press.

Stringer, R., \& Sang, S. (2009). Producers, processors, and procurement decisions: The case of vegetable supply chains in china. World Development, 37(11), 1773-17801. doi:10.1016/j. worlddev.2008.08.027

Sutopo, W., Hisjam, M., \& Yuniaristanto. (2012). An agri-food supply chain model to empower farmers as supplier for modern retailer using corporate social responsibility activi- 
ties on deteriorated product. Proceedings of the International Multi Conference of Engineers and Computer Scientists, 2, 1-5. doi:10.1007/978-94-007-5651-9_14

Tangpong, C., Hung, K.T., \& Li, J. (2014). Agent-system co-development in supply chain research: Propositions and demonstrative findings. Journal of Operations Management, 32(4), 154174. doi:10.1016/j.jom.2014.03.002

Taylor, D., \& Fearne, A. (2006). Towards a framework for improvement in the management of agri-food SCs. Supply Chain Management: An International Journal, 11(5), 379-384. doi:10.1108/13598540610682381

United Nations Conference on Trade and Development. (2009). World Investment Report 2009 on Transnational Corporations, Agricultural Production and Development. Geneva: UNCTAD/ DIAE/2009. Retrieved from: http://unctad.org/en/docs/ wir2009_en.pdf

Van Der Vorst, J.G.A.J., Beulens, A.J.M., \& Van Beek, P. (2000). Modelling and simulating multi-echelon food systems.
European Journal of Operational Research, 122(2), 354-366. doi:10.1016/S0377-2217(99)00238-6

Widyarini, M., Simatupang, T.M., \& Engelseth, P. (2016). Social interaction and price transmission in multi-tier food supply chains. Journal of Operations and Supply Chain Management, 9(1), 110-128. doi:10.12660/joscmv9n1p110-128

Williamson, O.E. (1981). The Economics of organization: The transaction cost approach. American Journal of Sociology, 87(3), 548-577. doi:10.1086/227496

Young, L.M., \& Hobbs, J.E. (2002). Vertical linkages in agri-food supply chains: Changing roles for producers, commodity groups, and government policy. Review of Agricultural Economics, 24(2), 428-441. doi:10.1111/1467-9353.00107

Zylbersztajn, D., \& Miele, M. (2005). Stability of contracts in the Brazilian wine industry. Revista de Economia e Sociologia Rural, 43(2), 353-371. doi:10.1590/S0103-20032005000200008 


\section{Appendix}

Appendix 1. Scenario Differences in the Simulation Model

\begin{tabular}{|c|c|c|c|}
\hline Aspects & \multicolumn{3}{|c|}{ Scenario } \\
\hline $\begin{array}{l}\text { Available } \\
\text { information } \\
\text { before } \\
\text { cultivation }\end{array}$ & - & $\begin{array}{l}\text { - Demand requirements } \\
\text { - Prices }\end{array}$ & $\begin{array}{l}\text { - Demand requirements } \\
\text { - Prices } \\
\text { - SOP and Good Agricultural } \\
\text { Practices }\end{array}$ \\
\hline Agents & $\begin{array}{l}\text { - Pangalengan cluster farmers } \\
\text { in terms of Good Agricultural } \\
\text { Practices: } \\
\text { - Traditional method of farming } \\
\text { (15 farmers) } \\
\text { - Partially implement Good } \\
\text { Agricultural Practices (15 } \\
\text { farmers) } \\
\text { - Good Agricultural Practices ( } 20 \\
\text { farmers) } \\
\text { - Traditional market through } \\
\text { intermediaries }\end{array}$ & $\begin{array}{l}\text { - Pangalengan cluster farmers } \\
\text { in terms of Good Agricultural } \\
\text { Practices: } \\
\text { - Traditional method of farming } \\
\text { (15 farmers) } \\
\text { - Partially implement Good } \\
\text { Agricultural Practices ( } 15 \\
\text { farmers) } \\
\text { - Good Agricultural Practices ( } 20 \\
\text { farmers) } \\
\text { - Traditional market through } \\
\text { intermediaries }\end{array}$ & $\begin{array}{l}\text { - Pangalengan cluster farmers } \\
\text { in terms of Good Agricultural } \\
\text { Practices: } \\
\text { - Traditional method of farming } \\
\text { (15 farmers) } \\
\text { - Partially implement Good } \\
\text { Agricultural Practices ( } 15 \\
\text { farmers) } \\
\text { - Good Agricultural Practices ( } 20 \\
\text { farmers) } \\
\text { - Traditional market through } \\
\text { intermediaries }\end{array}$ \\
\hline $\begin{array}{l}\text { Coordination } \\
\text { mechanism }\end{array}$ & & - Contract farming & $\begin{array}{l}\text { - Contract farming } \\
\text { - Joint decision making between } \\
\text { farmers to planning cultivation } \\
\text { and harvesting scheduling in } \\
\text { advance } \\
\text { - Information sharing and } \\
\text { collective learning between } \\
\text { farmers and structured market } \\
\text { to implement Good Agricultural } \\
\text { Practices and follow SOP }\end{array}$ \\
\hline \multirow[t]{2}{*}{ Agent behavior } & \multirow[b]{2}{*}{$\begin{array}{l}\text { - Farmers do not have planning } \\
\text { related to when to plant and how } \\
\text { much to plant. Therefore it is } \\
\text { random. }\end{array}$} & \multirow[b]{2}{*}{$\begin{array}{l}\text { - Farmers do not have planning } \\
\text { related to when to plant and how } \\
\text { much to plant. Therefore it is } \\
\text { random. }\end{array}$} & $\begin{array}{l}\text { Which farmers should plant, when } \\
\text { to plant, how much to plant, } \\
\text { when to harvest, how much to } \\
\text { harvest are based on cultivation } \\
\text { and harvesting scheduling. }\end{array}$ \\
\hline & & & $\begin{array}{l}\text { - Information sharing and collective } \\
\text { learning is implemented so that } \\
\text { farmers have the ability to learn } \\
\text { and change their behavior in } \\
\text { implementing SOP and GAP. With } \\
\text { this coordination mechanism, } \\
\text { farmers can improve their } \\
\text { agricultural practices. }\end{array}$ \\
\hline
\end{tabular}




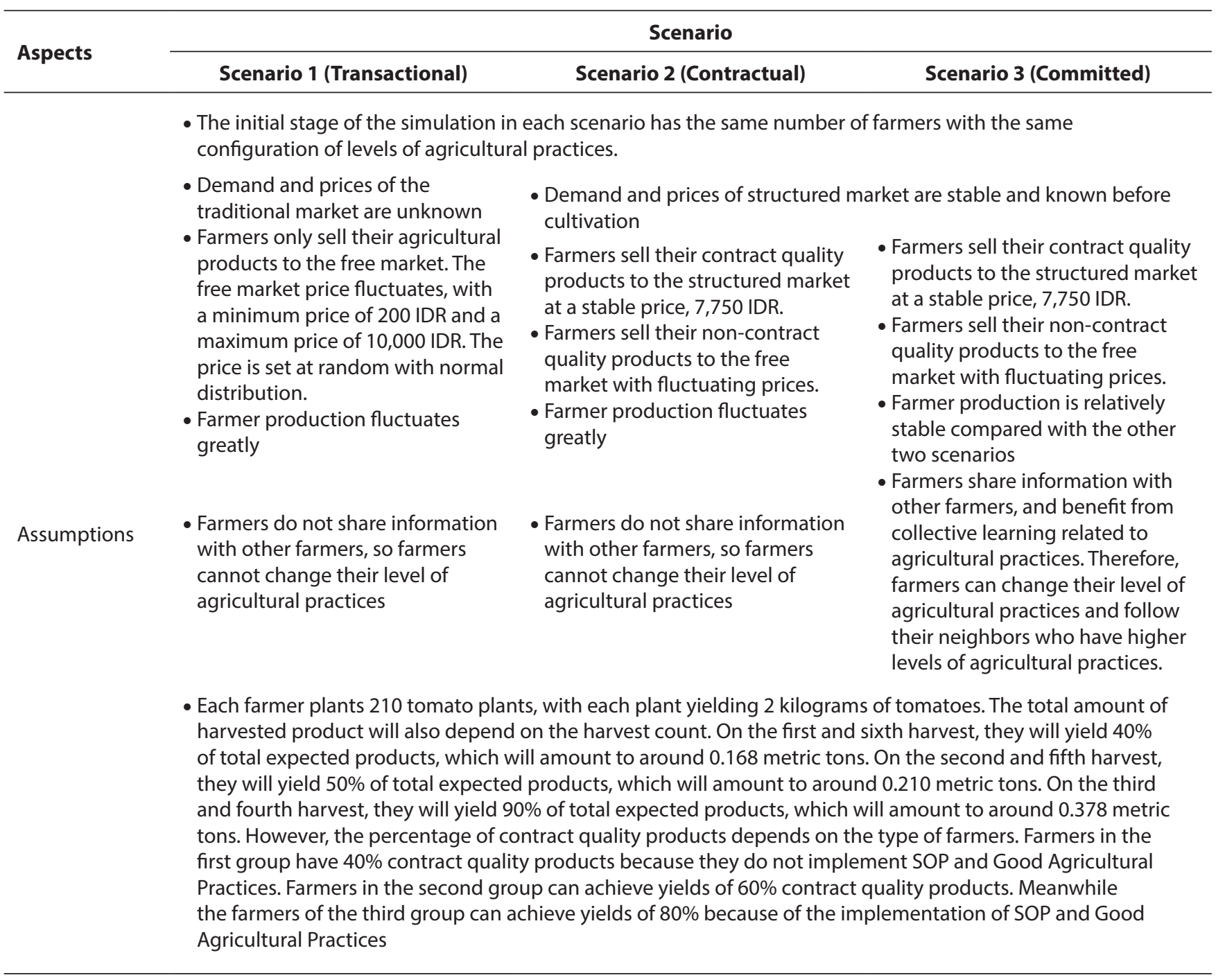




\section{Appendix 2. Simulation Flow in Scenario 1}

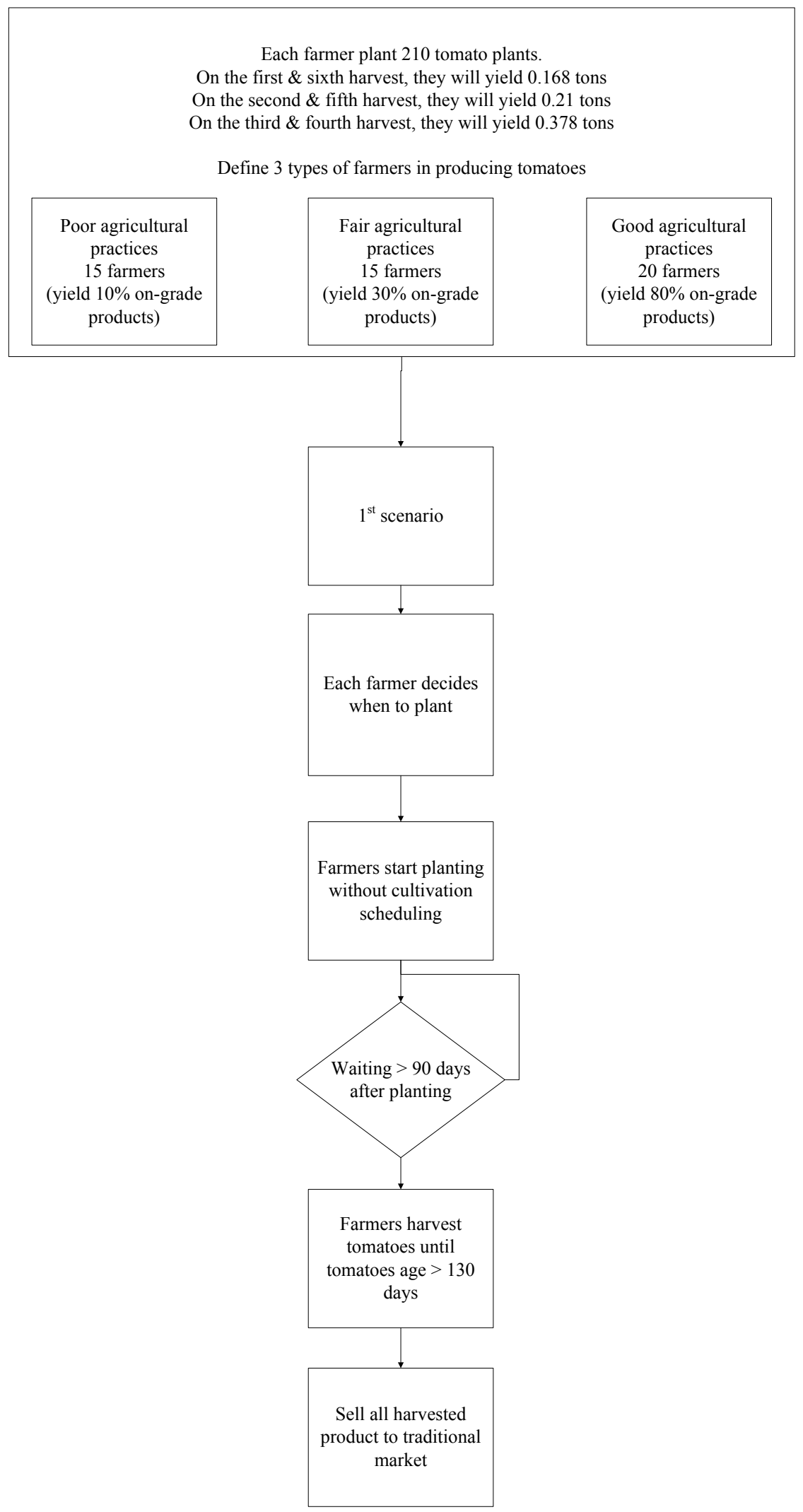




\section{Appendix 3. Simulation Flow in Scenario 2}

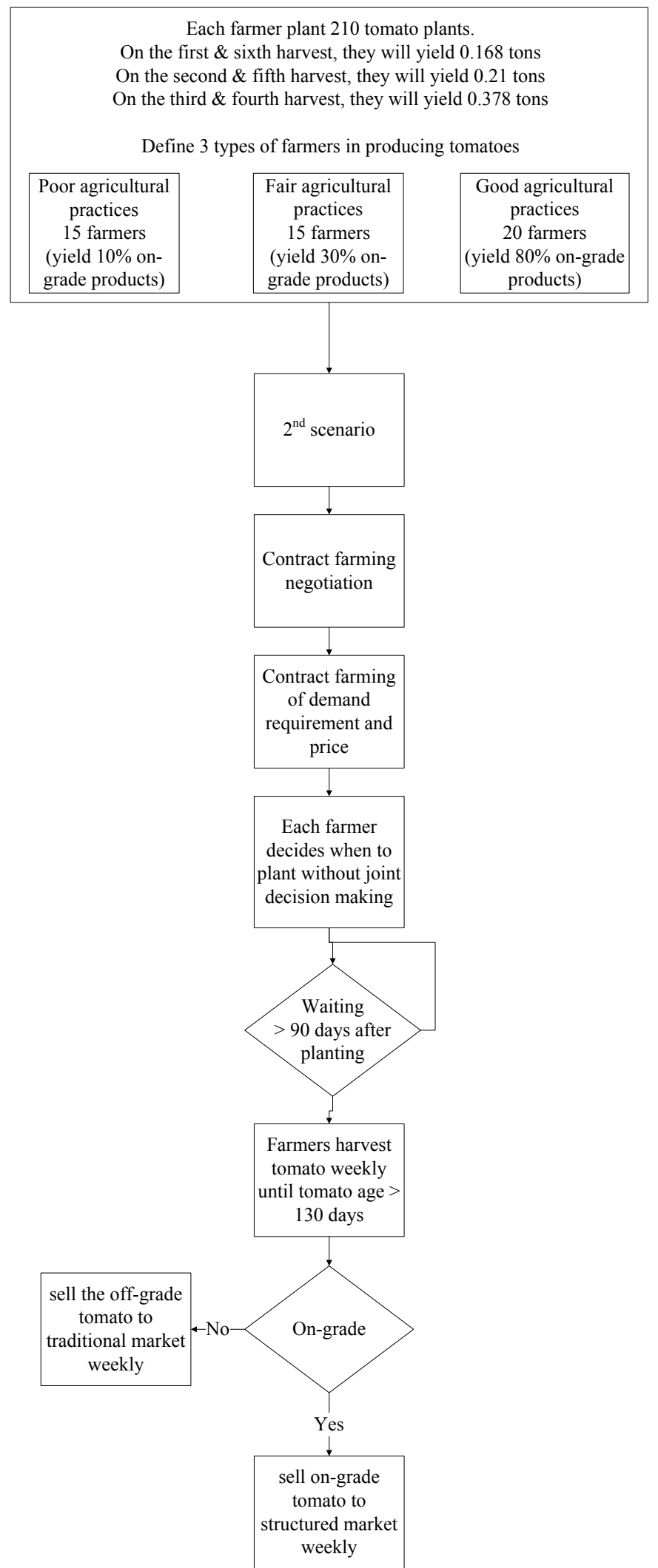




\section{Appendix 4. Simulation Flow in Scenario 3}

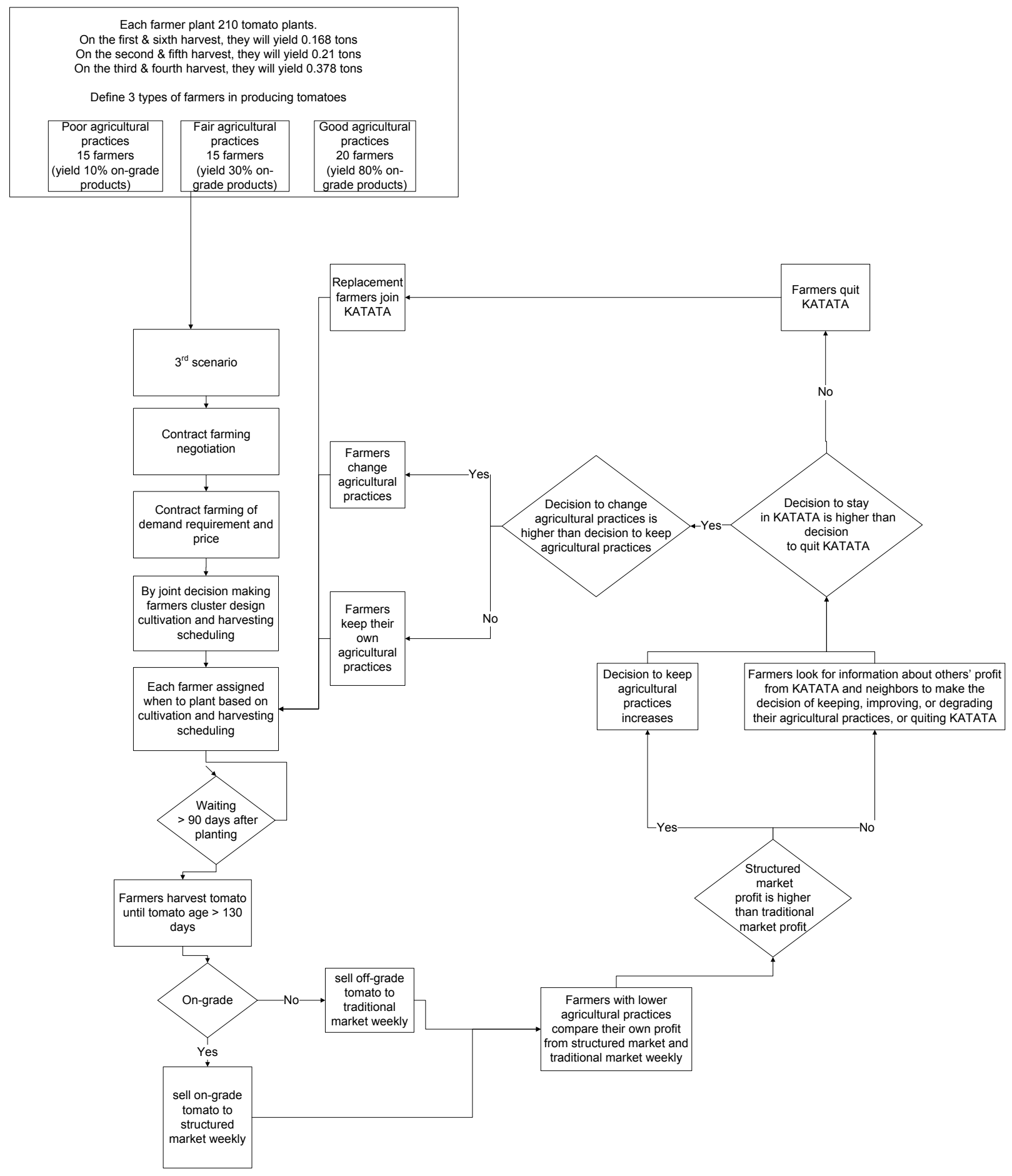

